\title{
The Effect of Internal Control Systems and Procrastination on Public Sector Employees
}

\author{
Afzal Izzaz Zahari", Jamaliah Said and Roshayani Arshad \\ Accounting Research Institute (ARI), UiTM Shah Alam, Selangor, MALAYSIA
}

\begin{abstract}
Internal control is a control mechanism that keeps in check the structure for it to operate within the intended parameters and target objectives. The paper offers an overview effectiveness of internal control on whether it achieves the purpose of control the organisation in reducing the laziness in public sector employees. The overall design approach is through the analysis of internal control systems from the Committee of Sponsoring Organisation (COSO) framework. Data was collected through the distribution of questionnaires towards 106 government organisations based on the contents of five components of internal control, which consist of the control environment, risk assessment, control activities, information and monitoring activities. A total sample of 118 government employees returned the questionnaires. Through the analysis of the internal control system, the overview is then observed on whether it would improve overall organisational performance. The study indicated that only a single component of internal control systems (monitoring) is an effective mechanism towards reducing procrastination. The usefulness on whether having strong controls can improve overall organisation performance in the public sector provides a different perspective as government employees have different motivations from private sector employees. The paper contributes towards understanding human behaviour in terms of its reaction towards control systems. It is also from a public sector viewpoint of which internal control effectiveness must be strong in order to increase effectiveness.
\end{abstract}

Keywords: Effectiveness, Internal Control Systems, Public Sector, Procrastination

JEL Classification: H83, Paper Type: Research

*Corresponding author: E-mail: afzalizzaz@gmail.com 


\section{INTRODUCTION}

Internal control has a central role that assures management and stakeholders. It provides overall risk management, which will reduce the levels of threats within the operation of the organization (Spira \& Page, 2003). A proper internal control system is important as it provides a guarantee that the achievement of organisational goals and target (Mizan et al., 2016). The components of internal control systems based on the Committee of Sponsoring Organisation (COSO) internal control framework had designed five major components of what makes an internal control system. Each of these components is interrelatable towards each other and have major roles in ensuring organisational effectiveness (Simer, 2013). Organisations are mainly concerned with the organisational performance of where the private sector is more focused on firm performance on maximising efficiency and profits, the public sector is more concerned on the achievement of targets and reducing redundancy in the organisation. Procrastination is an action of when an individual with intention postpones or delay tasks at hand of which they have low levels of self-control and regulation (Grund \& Fries, 2018). Study models had shown that the behaviours of procrastination are due to unattractive organisational goals and rewards that do not match with the user (Denison et al., 2003). Organisations often have limited resources and quality leadership in order to control procrastination. This is where the purpose of internal control comes into play on whether it has any effect on controlling such negative behaviour.

The government goals and objectives are carried out by government employees of where the people and citizens are the stakeholders. These stakeholders are general taxpayers that are concerned that their money is well spent within the governmental organisation. These actions of procrastination is an act of integrity violation that affects the overall performance of the government (Lasthuizen et al., 2011). The negative behaviour also reduces efficiency and overall output of an organisation. Government organisations are regularly associated with redundancy and inefficiency, which can be due to the country's economic structure (Hauner \& Kyobe, 2010). These authors stated that when a government has sufficient budget and spending, they will have higher levels of impact towards the society as countries with strong levels of finance and economy can extend their spending in the government. The concept of bureaucracy exists in government management of government structure as it provides certain checks and balances. Government employees may view bureaucracy as a hassle and will continue to procrastinate as they know that there will be delays in approvals of transactions (Soans \& Abe, 2016). The COSO framework is supposed to address these issues of identifying and eliminating the redundancy of an organisation (COSO, 2013a). The system's evaluation provides an overview of the effectiveness of internal control in the organisation.

The action of procrastination is a form of laziness that employees are not fully motivated to execute their task with adequate efficiency. The impact of when organisations personnel are lazy will have an overall effect on output (Grund \& Fries, 2018). The negative behaviour will influence individuals in the organisation where the tendency to conduct other negative behaviours will grow towards the individual (White, 2012). The person that acts with the action of laziness and procrastination will tend to cut corners and influence the overall work process. Individuals that have the character to procrastinate in an organisation are related to negative behaviours and will often make errors in their work (Gibson et al., 2014). This will reduce the overall output of the organisation of which time and money are lost with these negative behaviours. 


\section{STATEMENT OF THE PROBLEM}

The use of an internal control system is not only limited to the control functions of the organisation. The system has different capacity and affects which ensures organisational performance and goals are together achieved through an effective internal control system (Lansiluoto et al., 2016). The system is the main concern to most organisations as manipulations of the system often result in actions of misbehaviour such as fraud and corruption (Rosli et al., 2015). The weak internal control systems provide an opportunity for people in the organisation to abuse for their benefit (Bierstaker et al., 2006). The weak control will have an impact on other systems in the organisation, which will have an impact on organisational efficiency.

Government organisations have different motivations of where the principals are the people or citizens of the nation and agents are the government employees who are in charge of their respective departments and ministries (Jensen \& Meckling, 1976). The difference in motivation and goals are also different as public sector employees are only motivated by work efficiency process and achieving the set of internal goals that are given by the ruling government (Frank \& Lewis, 2004). These authors presented observations that government employees have a difference in terms of the approach of work and are geared towards helping other people in society. The area of being a useful, helpful government employee provides motivation for them to serve better in the government departments. The difference in terms of the rewards, values and goals makes it an objective issue in terms of identifying performance as compared to private sector employees that have direct monetary reward incentives and profit goals (Gibson et al., 2014).

The effect of opposing and using internal control systems for their benefit often lead to cases of fraud and corruption. The case study of an oil and gas industry shows that weak internal control systems reduce the effectiveness of governance in the organisation (Mizan et al., 2016). Cases in Malaysia had shown over the years that weak internal control systems provide opportunities for people to commit fraud. The case of Malaysian government employees in Sarawak that made false claims while working together with private companies costs the government nearly one hundred and fifty thousand dollars of money lost (Ling, 2018). The Sabah waters department case that saw the seizure of over twenty-seven million dollars cash and assets which belong to two government employees who are directors in the organisation (Lee, 2016). The findings in an oil and gas company had observed that the lack in the internal control system such as improper record keeping, low supervision of personnel, lack of monitoring and lack of control over petty cash expenditures resulted in opportunities for people to commit theft and acts of integrity violation (Mizan et al., 2016).

There are arguments towards the relevance of internal control as it is not an active system, the reaction when there is a crisis or special occasion will sometimes be too late before the system can adjust itself (Jensen, 1993). The cost of the system towards the organisation must also be taken into account, when the organisations are unable to afford an effective internal control system the purpose of internal control becomes irrelevant (Jack et al., 2010; Dorminey et al., 2012). The people in charge of the internal control systems must also be qualified in order to ensure the systems are adhered to in the organisation (Yu \& Neter, 1973). 


\section{LITERATURE REVIEW}

\subsection{Theory}

The development of control theory in sociology was through the understanding human behaviour in ensuring control and adhering to the laws set up by the people in the society. The need for control as a tool of order and stability, of which deviant behaviours are prevented had been argued throughout numerous discussions. The sociologist control theory perspective by Travis Hirshi observed that deviant behaviours could be explained through upbringing and not strongly related to the socioeconomic status of the person (Hirschi \& Gottfredson, 1995). The education received by the person will impact their behaviour in society. This means that deviant behaviours and integrity violations are mostly contributed to how people are brought up whether or not the control systems are in place to hold them. Prior to this development, there was another approach of control theory, which has the components of containment (Reckless, 1961). The author presents that the people in the society will behave accordingly when faced with social pressure that is enforced by social ostracism. The relation here is that when the person does not conform or follow the internal control systems, people or members of the organisation will ostracise the deviant person.

The understanding of control theory is one of the factors in ensuring the effectiveness of internal control systems. The organisation would not want to enforce draconian to employees that do not follow the system as it would nevertheless be counterproductive (Snider, 2002). Governments attempt in disciplining private organisations are often regarded as ineffective as each organisation has its working system. The form of control that governments are often involved is through labour law that states the responsibilities of the employee within the organisation and any deviance behaviour are punishable by set codes of conduct (Servais \& Blanpain, 2011). The theory here is related and suggests that people who are not following the internal control system are penalised for the misbehaviour.

\subsection{Internal Control Systems}

Internal control systems are part of the Management Control Systems (MCS), which consists of information which helps the users or organisations achieve their objectives (Atkinson et al., 2012). Control is when the set of tools, procedures and system is used by the employees in order for the organisation achieves their objectives. Systems are the set various parts of the organisation working together as a single complex dimension in order to achieve a common goal within the organisation (Shields et al., 2000). The importance of an MCS is that it is an overview of financial planning, evaluation, strategies, development and marketing of the whole organisation (Davila \& Foster, 2007). Internal control systems, which are a part of MCS, is the form and use of control by the employees in the organisation that mitigate and manage control (Kendrick, 2000). Through having a good control system, it does not just improve governance in the organisation but is also a form of risk management (Spira \& Page, 2003). The importance of managing risk is that it would help reduce losses associated with losing control. When there are a weak or ineffective internal control system, there are bound to be an abuse of the system that will eventually damage the organisation (Petrovits et al., 2011). The weak system does not only damage the organisation financially, but other forms of damage such as reputation are also affected.

Certain conditions, such as behaviour are observed to have an impact on the internal control system. When the individual operating the internal control system does not 
correctly comply with the systems requirement, the overall effectiveness and quality of the internal control system will be affected (Yu \& Neter, 1973). The quality of the internal control system depends on the people operating it as it does not mean that the system is highly reliable. The concern here is that when there are low levels of the control system, there will be higher levels of unethical behaviour that will impact organisational performance. Studies in the Nigerian public sector indicated that when there are low levels of internal control systems, there is an increase in project mismanagement (Babatunde \& Dandago, 2014).

The need for an efficiency wage for government employees is a way to ensure that sufficient control over the organisation (Besley \& McLaren, 1993). The employees are not given wages that are too low that will make them inclined to ignore the control system or too high of which it will be too costly for the organisation. Studies in the retail industry had shown that when employees are given high levels of wages, the acts of theft is negatively correlated (Chen \& Sandino, 2012). The use of penalties such as high levels of fines influences the adherence of control in the organisation (Hansen, 1997). The observation here shows that when the fine is set too low, the people in the organisation are not afraid to conduct acts of theft.

These are some of the control settings for ensuring an effective internal control system. The overall conditions are stating that human attitude, upbringing, adherence, wages, compliance, organisational costs and other factors could influence the quality of internal control system (Yu \& Neter, 1973; Hansen, 1997; Ofori, 2011; Chen \& Sandino, 2012; Babatunde \& Dandago, 2014). The quality of internal control systems that are adopted will have an impact on the organisation's effectiveness in achieving its goals (Bowrin, 2004; Khlif \& Samaha, 2016)

\subsection{Procrastination}

The act of procrastination is from the act of delaying work or actions that can be due to factors that can influence such behaviour (Ferrari et al., 1995; Fernie et al., 2017). The studies on procrastination could be subjective as human traits and behaviour changes over time and through socioeconomic conditions that make the testing of procrastination an open-ended question (Kantor, 1953). Empirical tests are limited if the conditions are met and satisfactory. Overall results such as studies of examination results or employee's job performance and delivery are often the gauge of measuring procrastination. Studies had observed the relationship between active and passive procrastinators of which people who are delaying their work on the habits or routine (Wessel et al., 2019). Their findings suggested that there are some differences in terms of the behaviour of the people who are actively delaying their work as compared to others that do not delay work that will influence overall results and performance.

The working conditions, such as having proper motivations, are some of the influences that can make a worker procrastinate (Grund \& Fries, 2018). Through having proper incentives and rewards for the employees will help reduce the negative behaviours. The study on university students had observed that the acts of procrastination are influenced by task aversiveness, time management, laziness, and the act of opposing control (Jami \& Afzal, 2018). Task aversiveness is the situation of when the task is not enjoyable or unfavourable to the person at hand of which makes the person resort to procrastination. The study on the impact of regulation towards procrastination had shown that the sense of control provides a mediating effect that can control and improve behaviours for the better (Afzal \& Jami, 2018)

Laziness is another context of (Poole, 2013)procrastination. Laziness is the act of not willing to use their energy to finish the task at hand (Jami \& Afzal, 2018). Employees are 
lazy when they are not completing their task and purposely procrastinating the process (Schraw et al., 2007). The quality of work involved influences a person's laziness when the work is interesting or engaging toward the person; they are then willing to put in more effort and energy in order to finish the task at hand (Bowen, 2003). There are other approaches that saw people having the right to be lazy; this is when they do not have a proper focus on the task at hand (Poole, 2013). The misdirection and weak purpose make the employee themselves not motivated and lazy towards the task. Having proper organisational goals and objectives contributes towards reducing these behaviours of procrastination and improving performance (Mintzberg, 1973; Koh \& Boo, 2001; Lyubomirsky et al., 2005; Gregory et al., 2009)

The act of laziness is also a theft of time for the organisation (Henle et al., 2010). Studies on surrounding indicated that when people perceive that there is weak control over the organisation, the employee will abuse these conditions and procrastinate through laziness (Henle et al., 2010). The weak conditions, such as having a weak control environment, make it possible for the employee to misbehave (Hollinger \& Clark, 1983). Their study had shown that when there is no impact or penalties towards misbehaviours, the employee will continue to deliver lower outputs that impact overall organisational performance.

\section{RESEARCH METHODOLOGY}

\subsection{Research Development}

In the relationship control paradigm, having control is generally an essential part of the organisation. The tradeoff of having more control or reduction in the number of control influences the conditions of the organisation. Control environments serve as having the sets of standards and processes that are the core component of internal control in an organisation (COSO, 2013b). Through having more control over the control environment would promote ethical behaviour within the organisation (Lewis, 2016). Therefore a negative relationship between control environment and procrastination is proposed:

\section{H1: The level of control environment is negatively related to the level of procrastination}

Risk assessment is towards the organisation's objectives in achieving its set target goals (COSO, 2013b). The impact of having motivations in the organisation would deter acts of unethical behaviour (Grund \& Fries, 2018). Through having specific objectives that are in line with individual passion will help the employee work harder and not delay their work (Schraw et al., 2007). Hence it is posited that:

\section{H2: The level of risk assessment is negatively related to the level of procrastination}

Control activities the policies, rules, regulation, code of conduct and procedures that employees in the organisation must adhere to (COSO, 2013b). Having rules and regulation promote positive behaviours within the organisation (Martin et al., 2013). It is proposed that:

\section{H3: The level of control activities is negatively related to the level of procrastination}

Information and communication are essential in the COSO framework as the information used for continuous operations and decision making (COSO, 2013b). Through having 
effective communication, an effective information can be relayed to have better decision making decisions in the organisation (Atkinson et al., 2012). Hence, it is hypothesized that:

H4: The level of information and communication is negatively related to the level of procrastination

The monitoring of the organisation includes the observation of activities within the organisations (COSO, 2013b). Having leaders or management that closely monitors employees helps in terms of improving efficiency (Staicu et al., 2013). It is proposed that:

H5: The level of monitoring is negatively related to the level of procrastination

Overall, the whole internal control systems must have an adequate quality level in order for the system to deliver its effectiveness (Khlif \& Samaha, 2016). An effective internal control system is supposed to help mitigate problems and reduce negative behaviours such as procrastination (Agbejule \& Jokipii, 2009; Henle et al., 2010; Ahmad et al., 2012; Arwinge, 2013). The final hypothesis proposed is that:

H6: The level of internal control systems is negatively related to the level of procrastination

\subsection{Survey Development}

The five components of COSO are adopted based on the research on various internal control studies (Agbejule \& Jokipii, 2009; Jokipii, 2009; Lansiluoto et al., 2016). The determinant or dependent variable of procrastination is based on studies of integrity violations (Huberts \& Lasthuizen, 2014; Graaf et al., 2017).

\subsection{Research Model}

The items of internal control systems are based on the five components of the COSO framework, which consist of the control environment, risk assessment, control activities, information and monitoring activities (COSO, 2013b). The relationship of these internal control systems is then reflected towards the action of procrastination of the act of laziness in the organisation (Jami \& Afzal, 2018).

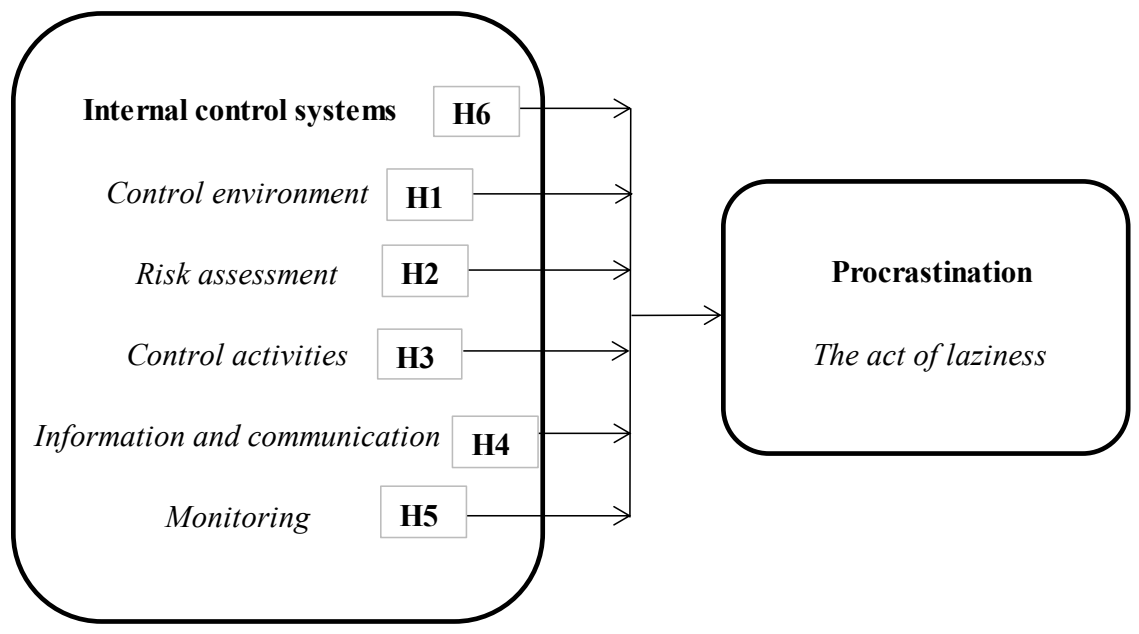

Figure 1. Research model with hypothesis indicators 


\subsection{Sample and Data Collection}

The data is collected through the distribution of questionnaires to the Malaysian federal government department's employees. The sample is ranging from the selection of employees that are defined as managers and executives in the government organisation. These include government officials that have roles as managers, which have the responsibility of determining, direct and advising government policies (Malaysian Ministry of Human Resource, 2013). The managers in government departments are employees that are qualified professionals and have managerial duties (Public Service Department of Malaysia, 2002). This grading system is that employees between the range of grade 41 and 54 are required to have managerial roles in the government departments.

The Malaysian government has a total of 27 federal ministries, and these ministries have components of the administrative, department and statutory bodies under their supervision (Department of Information Malaysia, 2017). There are a total of 106 departments identified for distribution of questionnaires. Past studies had examined different aspects of government departments of their timeline such as observing specific roles in the department such as audit managers (Mucciarone, 2008; Mucciarone \& Neilson, 2011; Nadiah Hassan et al., 2015). These studies had observed specific roles, such as audit managers have and the performance impact of government departments.

The research was a cross-sectional study towards the specific level of employees in the organisation that are managers (Creswell, 2003). The survey was sent out through letters and online distribution. There were a total of 530 questionnaires sent out, and a total of 252 had answered the survey. However, as the survey aims only to assess manager-level employees, only 118 samples are qualified and fulfil the requirements $(\mathrm{N}=530, \mathrm{n}=252$, response rate $=47.5 \%)$. The participants were assured that their responses are confidential and would not identify them individually. The profile summary of the respondents of the survey is presented in Table 1.

Table 1. Respondents profile

\begin{tabular}{lllll}
\hline Gender & Frequency & Percent & Valid Percent & Cumulative Percent \\
\hline Male & 57 & 48.3 & 48.7 & 48.7 \\
Female & 60 & 50.8 & 51.3 & 100.0 \\
\hline Total & 117 & 99.2 & 100.0 & \\
\hline Missing & 1 & 0.8 & & \\
\hline Total & 118 & 100.0 & & Cumulative Percent \\
\hline Age & Frequency & Percent & Valid Percent & 14.4 \\
\hline 20-30 Years & 17 & 14.4 & 14.4 & 59.3 \\
31-40 Years & 53 & 44.9 & 44.9 & 90.7 \\
41-50 Years & 37 & 31.4 & 31.4 & 100.0 \\
51 and above & 11 & 9.3 & 9.3 & \\
\hline Total & 118 & 100.0 & 100.0 & Cumulative Percent \\
\hline Qualification & Frequency & Percent & Valid Percent & C.9 \\
\hline Not available & 7 & 5.9 & 5.9 & 70.0 \\
Diploma & 12 & 10.1 & 10.1 & 96.3 \\
Degree & 64 & 54.2 & 54.2 & 100.0 \\
Masters & 31 & 26.3 & 26.3 & \\
PhD & 4 & 3.4 & 3.4 & \\
\hline Total & 118 & 100.0 & 100.0 & \\
\hline
\end{tabular}

The total male respondents are $48.7 \%$, almost half of the total sample. The majority of the respondents are aged between 31 to 40 years old. The lowest quantum is 51 years old 
and above. The majority of respondents are certificate and degree holders. The basic degree holders are the highest number of the respondent with a count of 64 people.

\section{ANALYSIS AND RESULTS}

\subsection{Reliability Test}

Data were analysed using the Statistical Package for Social Science (SPSS). The process summary had excluded three cases as some of the values were missing. A reliability test based on the Cronbach Alpha statistic was used to test whether the data is reliable. The data were tested for internal consistency of the items from internal control systems and procrastination using Cronbach's coefficient alpha. The reliability coefficient for the scale was 0.721 that represents a satisfactory level of reliability (Creswell, 2003).

\subsection{Kaiser-Meyer-Olkin and Barlett test}

The Kaiser-Meyer-Olkin (KMO) test was done in order to determine if the data was appropriate for factor analysis. The values for KMO sample of adequacy was 0.857 and that data analysed through factor analysis will be quite informative (Hair et al., 2010). Bartlett's test of sphericity shows that there is a statistical significance of the data $(p<0.001)$.

\subsection{Correlation matrix}

The correlation matrix of the variables in the regression model is given in Table 2 . The measures of all the variables are negatively correlated with procrastination. This coincides with the principle that any forms of control systems will help deter procrastination. The control systems components and overall internal control systems are significantly correlated with procrastination.

Table 2. Correlation matrix of variable

\begin{tabular}{|c|c|c|c|c|c|c|c|}
\hline Variables & Procrastination & $\begin{array}{l}\text { Control } \\
\text { Environment }\end{array}$ & Risk & $\begin{array}{l}\text { Control } \\
\text { Activities }\end{array}$ & Information & Monitoring & ICS \\
\hline Procrastination & 1.000 & & & & & & \\
\hline $\begin{array}{l}\text { Control } \\
\text { Environment }\end{array}$ & $-0.205^{*}$ & 1.000 & & & & & \\
\hline Risk & $-0.194^{*}$ & 0.733 & 1.000 & & & & \\
\hline $\begin{array}{l}\text { Control } \\
\text { Activities }\end{array}$ & -0.099 & 0.625 & 0.727 & 1.000 & & & \\
\hline Information & $-0.196 *$ & 0.694 & 0.761 & 0.619 & 1.000 & & \\
\hline Monitoring & $-0.224^{* *}$ & 0.645 & 0.692 & 0.753 & 0.703 & 1.000 & \\
\hline $\begin{array}{l}\text { Internal Control } \\
\text { Systems (ICS) }\end{array}$ & $-0.213^{* *}$ & 0.840 & 0.898 & 0.850 & 0.877 & 0.881 & 1.000 \\
\hline
\end{tabular}

\subsection{Hypothesis testing}

The hypotheses of the study are tested using multiple regression based on the following multiple regression model (Field, 2013)

$$
\hat{y}=\alpha+b_{1} x_{1}+b_{2} x_{2}+b_{3} x_{3}+b_{4} x_{4}+b_{5} x_{5}+\mu
$$


This is where $\hat{y}$ is the expected value of the dependent variable, which is procrastination. The values of $x_{1}$ to $x_{5}$ are the predictor variables of the internal control systems. The residuals from the regression equation suggest that there are no serious violations of assumptions of normality.

Table 3 represents the multiple regression analysis for the equation with a total sample of 118 managers. A total of six regressions run were performed. The results indicate that only the monitoring of activities as a significant regression model. The other measures of internal control systems such as control environment, risk management, control activities, information and communication, together with the overall system, do not have a significant relationship towards procrastination. The R-square is considered adequate as the objective of the model to assess the direction and strength of the relationship of control systems and procrastination.

Table 3. Result of multiple regression analysis

\begin{tabular}{llcl}
\hline Variable & Coefficient & t-value & $\boldsymbol{p}$-value \\
\hline $\begin{array}{l}\text { Procrastination } \\
\text { Monitoring }\end{array}$ & -0.224 & -2.472 & $0.015^{*}$ \\
Model & (R-square=0.224;Adjusted =0.50) & & \\
\hline * Significant at the 0.05 level & &
\end{tabular}

\section{CONCLUSIONS, LIMITATIONS AND FUTURE RESEARCH}

Internal control systems ensure that the processes in the organisation are directed to achieve the set-out goals and objectives (COSO, 2013a). The control factors in a controlled environment function as the overall structure of an organisation. The case study of the state department in the United States had shown some of the importance of the control environment towards ethical behaviours (Lewis, 2016). This study contradicts those assumptions only in terms of the significant impact it will have; however, in terms of correlation relationship, there are significant values that can be seen upon the influence of control environments. A risk assessment or risk management is more related to the organisations expected risks. The layout of risk assessment is more related to whether or not the goals are achieved with the existence of unethical behaviour such as procrastination. The findings show that the relationship between procrastination and risk management as negative but holds no significant relationship. The organisation would be able to design strategies on their risk assessments, but these actions would not hold any significant impact on procrastination.

The control activities are related to the set of rules in place within the organisational structure (COSO, 2013b). Though past studies indicated that having rules and regulation are supposedly promote ethical behaviours, the studies indicate otherwise (Martin et al., 2013). The assumption here is that personal values come into play when a person procrastinate. The value in the level of ethical reasoning of the individual has a stronger influence as compared to the following control activities. Other factors such as employees pay or importance of work may be the reason for procrastination as based on previous studies (Grund \& Fries, 2018). The levels of information available are assumed to be able to influence decision making in making positive and better actions throughout the organisation (Atkinson et al., 2012). The leaders can make better ethical judgements when there is more information in the organisation (Douglas et al., 2001). The actions of procrastination are not affected may be due information on individual values is not general information in an organisation. Internal control systems only function as a system catalyst, and individualistic behaviours are always changing thus inclined to be unpredictable. 
Monitoring of activities is a standard method in ensuring organisational efficiency (Hansen, 1997). Internal control systems suggest that monitoring of activities in the ongoing activities such as reports that are relevant information for the manager to take action. In the case of procrastination in the public sector, such control systems that are related in the Malaysian government is the Annual Work Targets or locally known as "Sasaran Kerja Tahunan" (SKT) that ensures that each of the government employees achieve their targets and maintain a certain level of quality of service (Public Service Department of Malaysia, 2011). The yearly measurement systems is a form of monitoring control that senior management of government organisations can act upon in order to deter acts of procrastination. Employees in the public sector who do not achieve such required criterion will face the risk of not obtaining any increments of incentives by the government.

The overall context of whether internal control systems are supposed to control unethical behaviour of procrastination may require further investigation. Though prior studies had shown that an internal control system might control negative behaviours though not strongly related to procrastination (Agbejule \& Jokipii, 2009; Henle et al., 2010; Ahmad et al., 2012; Arwinge, 2013). The overall usefulness of the system still provides a strong structure in organisations in terms of other values and compliance based environment. A study is an alternative approach in showing that such control systems are not an influencing factor in controlling personal human behaviours.

\subsection{Limitation}

The study is limited to public sector personnel. The act of procrastination in terms of evaluation is always subjective and could be dependable on other factors such as race, culture or social upbringing (Mansor \& Kennedy, 2000). Several other values that can be put in place when determining a reason why people procrastinate in their work, such as motivation or monetary rewards (Grund \& Fries, 2018).

\subsection{Future Studies}

The inclusion of the private sector perspective may provide different viewpoints of procrastination. The effects from the age, gender, education and experience of work may show different values in terms of values of procrastination. There are different scopes that can be inserted in terms of evaluating the effectiveness of internal control systems towards controlling behaviours. These areas of research provide information to managers on what approaches can be taken in order to control levels of procrastination.

\section{ACKNOWLEDGEMENTS}

We are indebted to the Malaysian Institute of Integrity (IIM) and the Accounting Research Institute (ARI, UiTM) in giving us the support for this project. We appreciate the reviews and comments made by academicians on earlier drafts of this paper. Many thanks to the government agencies, organisations and commissions that participated in the project.

\section{REFERENCES}

Afzal, S., \& Jami, H. (2018). Time Perspective, Control, and Affect Mediate The Relation Between Regulatory Mode and Procrastination. Journal of Behavioural Sciences, 28(1), 51-69.

Agbejule, A., \& Jokipii, A. (2009). Strategy, Control Activities, Monitoring and Effectiveness. Managerial Auditing Journal, 24(6), 500-522. https://doi.org/10.1108/02686900910966503 
Ahmad, H. A., Othman, R., Othman, R., \& Jusoff, K. (2012). The Effectiveness of Internal Audit in Malaysian Public Sector. Journal of Accounting and Auditing, 5(OCTOBER).

Arwinge, O. (2013). Internal Control: A study of Concept and Themes. Springer Science \& Business Media. United Kingdom: Springer. https://doi.org/10.1007/978-3-7908-2151-2

Atkinson, A. A., Kaplan, R. S., Matsumura, E. M., \& Young, S. M. (2012). Management Accounting: Information for Decision-making and Strategy Execution. Essex: Pearson (6th ed.). Pearson.

Babatunde, S. A., \& Dandago, K. I. (2014). Internal Control System Deficiency and Capital Project Mis-management in the Nigerian Public Sector. Procedia - Social and Behavioral Sciences, 164(August), 208-221. https://doi.org/10.1016/j.sbspro.2014.11.069

Besley, T., \& McLaren, J. (1993). Taxes and Bribery : The Role of Wage Incentives. The Economic Journal, 103(416), 119-141.

Bierstaker, J. L., Brody, R. G., \& Pacini, C. (2006). Accountants' Perceptions regarding Fraud Detection and Prevention Methods. Managerial Auditing Journal, 21(5), 520-535. https://doi.org/10.1108/02686900610667283

Bowen, E. R. (2003). Student engagement and its relation to quality work design: A review of the literature. Action Research Exchange, 2(1), 1-13.

Bowrin, A. R. (2004). Internal control in Trinidad and Tobago Religious Organizations. Accounting, Auditing $\quad \& \quad$ Accountability Journal, 17(1), 121-152. https://doi.org/10.1108/09513570410525238

Chen, C. X., \& Sandino, T. (2012). Can Wages Buy Honesty? The Relationship Between Relative Wages and Employee Theft. Journal of Accounting Research, 50(4), 967-1000. Retrieved from http://onlinelibrary.wiley.com/doi/10.1111/j.1475-679X.2012.00456.x/abstract

COSO. (2013a). Internal Control: Integrated Framework, (May), 10. https://doi.org/978-1-93735239-4

COSO. (2013b). Internal Control: Integrated Framework (Executive Summary). Retrieved from http://coso.org/lC-IntegratedFramework-summary.htm

Creswell, J. W. (2003). Research Design: Qualitative, quantitative, and mixed methods approaches. SAGE. Retrieved from https://books.google.com.my/books?id=YcdIPWPJRBcC\&printsec=frontcover\&source=gbs ViewAPI\&redir esc $=y \# v=$ onepage\&q\&f=false

Davila, A., \& Foster, $\bar{G}$. (2007). Management control systems in early-stage startup companies. Accounting Review, 82(4), 907-937. https://doi.org/10.2308/accr.2007.82.4.907

Denison, D., Ashkanasy, N., Wilderom, C., Peterson, M., Cooper, C. L., Cartwright, S., \& Earley, P. C. (2003). The Handbook of Organizational Culture and Climate. Administrative Science Quarterly (Vol. 48). https://doi.org/10.1017/CBO9781107415324.004

Department of Information Malaysia. (2017). Senarai Jabatan atau Agensi Kerajaan Persekutuan. Retrieved May 25, 2017, from http://pmr.penerangan.gov.my/index.php/maklumatkenegaraan/12071-senarai-jabatanagensi-kerajaan-persekutuan.html

Dorminey, J., Scott Fleming, A., Kranacher, M. J., \& Riley, R. A. (2012). The Evolution of Fraud Theory. Issues in Accounting Education, 27(2), 555-579. https://doi.org/10.2308/iace-50131

Douglas, P. C., Davidson, R. A., \& Schwartz, B. N. (2001). The Effect of Organizational Culture and Ethical Orientation on Accountants' Ethical Judgement. Journal of Business Ethics, 34(2), 101-121.

Fernie, B. A., Bharucha, Z., Nikčević, A. V., Marino, C., \& Spada, M. M. (2017). A Metacognitive Model of Procrastination. Journal of Affective Disorders, 210(August 2016), 196-203. https://doi.org/10.1016/j.jad.2016.12.042

Ferrari, J. R., Johnson, J. L., \& McCown, W. G. (1995). Procrastination Research. In Procrastination and Task Avoidance (pp. 21-46). Springer.

Field, A. (2013). Discovering Statistics Using IBM SPSS Statistics (4th Edition). SAGE Publications Limited.

Frank, S. A., \& Lewis, G. B. (2004). Government Employees: Working Hard or Hardly Working? The American Review of Public Administration, 34(1), 36-51. https://doi.org/10.1177/0275074003258823

Gibson, J. L., Donnelly, J. H., Ivancevich, J. M., \& Konopaske, R. (2014). Organizations: Behaviour, Structure, Processes. McGraw-Hill Irwin. 
Graaf, G. de, Huberts, L., \& Strüwer, T. (2017). Integrity Violations and Corruption in Western Public Governance: Empirical Evidence and Reflection from the Netherlands. Public Integrity, $O(0)$, 1-19. https://doi.org/10.1080/10999922.2017.1350796

Gregory, B. T., Harris, S. G., Armenakis, A. A., \& Shook, C. L. (2009). Organizational Culture and Effectiveness: A study of values, attitudes, and organizational outcomes. Journal of Business Research, 62(7), 673-679. https://doi.org/10.1016/j.jbusres.2008.05.021

Grund, A., \& Fries, S. (2018). Understanding Procrastination: A motivational approach. Personality and Individual Differences, 121(March 2017), 120-130. https://doi.org/10.1016/j.paid.2017.09.035

Hair, J. F., Anderson, R. E., Tatham, R. L., \& Black, W. C. (2010). Multivariate Data Analysis: A global perspective. Upper Saddle River (7th Editio). New Jersey: Prentice Hall.

Hansen, S. C. (1997). Designing Internal Controls: The interaction between efficiency wages and monitoring. Contemporary Accounting Research, 14(1), 129-163. https://doi.org/10.1111/j.1911-3846.1997.tb00522.x

Hassan, N., Rahmat, M. M., \& Muhammudun, Z. M. (2015). Sistem kawalan dalaman, sokongan pengurusan dan keberkesan audit dalaman sektor awam di Malaysia. Asian Journal of Accounting and Governance, 12, 1-12. Retrieved from http://journalarticle.ukm.my/9581/1/8518-33162-1-PB.pdf

Hauner, D., \& Kyobe, A. (2010). Determinants of Government Efficiency. World Development, 38(11), 1527-1542. https://doi.org/10.1016/j.worlddev.2010.04.004

Henle, C. A., Reeve, C. L., \& Pitts, V. E. (2010). Stealing time at work: Attitudes, social pressure, and perceived control as predictors of time theft. Journal of Business Ethics, 94(1), 53-67. https://doi.org/10.1007/s10551-009-0249-z

Hirschi, T., \& Gottfredson, M. R. (1995). Control Theory and The Life-course Perspective. Studies on Crime \& Crime Prevention. Retrieved from http://psycnet.apa.org/psycinfo/1996-34555001

Hollinger, R. C., \& Clark, J. P. (1983). Theft by Employees. Lexington, MA: D.C. Heath.

Huberts, L., \& Lasthuizen, K. (2014). The Integrity of Governance. (R. Fouchet \& T. Brandsen, Eds.), Palgrave Macmillan, London (First Edit). France.

Jack, D., Arron Scott, F., \& Mary-Jo, R. (2010). Beyond The Fraud Triangle. THE CPA Journal2, $80(7), 17-23$.

Jami, H., \& Afzal, S. (2018). Prevalence of Academic Procrastination and Reasons for Academic Procrastination in University Students. Journal of Behavioural Sciences, 28(1).

Jensen, M. C. (1993). The Modern Industrial Revolution, Exit, and the Failure of Internal Control Systems the Failure of Internal Control Systems. Journal of Finance, 48(3), 831-880. https://doi.org/10.1111/j.1540-6261.1993.tb04022.x

Jensen, M. C., \& Meckling, W. H. (1976). Theory of the Firm: Managerial Behavior, Agency Costs and Ownership Structure. Journal of Financial Economics, 3(4), 305-360.

Jokipii, A. (2009). Determinants and Consequences of Internal Control in Firms: A contingency theory based analysis. Journal of Management and Governance, 14(2), 115-144. https://doi.org/10.1007/s10997-009-9085-x

Kantor, J. R. (1953). The logic of modern science.

Kendrick, M. (2000). Internal Control: Guidance for Directors on the Combined Code (The Turnbull Report). Risk Management, 2(4), 65-69. https://doi.org/10.1057/palgrave.rm.8240072

Khlif, H., \& Samaha, K. (2016). Audit committee activity and internal control quality in Egypt: Does external auditor's size matter? Managerial Auditing Journal, 31(3), 269-289. https://doi.org/10.1108/02656710210415703

Koh, H. C., \& Boo, E. H. Y. (2001). The link between organizational ethics and job satisfaction: A study of managers in Singapore. Journal of Business Ethics, 29(4), 309-324. https://doi.org/10.1023/A:1010741519818

Lansiluoto, A., Jokipii, A., \& Eklund, T. (2016). Internal Control Effectiveness: A clustering approach. Managerial Auditing Journal, 31(1), 5-34. https://doi.org/10.1108/MAJ-08-20130910

Lasthuizen, K., Huberts, L., \& Heres, L. (2011). How to Measure Integrity Violations: Towards a Validated Typology of Unethical Behavior. Public Management Review, 13(3), 383-408. https://doi.org/10.1080/14719037.2011.553267 
Lee, S. (2016). Sabah Water Department Director Released on Bail. The Star Online, p. 1. Retrieved from https://www.thestar.com.my/news/nation/2016/10/16/sabah-water-opsdirector-released/\#4G8tZtk5cOKTBWfl.9

Lewis, W. E. (2016). Control Environment for Ethical Behaviour.

Ling, S. (2018). Four BTN Officers among 10 Arrested Over RM600,000 in False Claims. The Star Online, p. 1. Retrieved from https://www.thestar.com.my/news/nation/2018/08/02/four-btnofficers-among-10-arrested-over-rm600000-in-false-claims/

Lyubomirsky, S., King, L., \& Diener, E. (2005). The benefits of frequent positive affect: Does happiness lead to success? Psychological Bulletin, 131(6), 803-855. https://doi.org/10.1037/0033-2909.131.6.803

Malaysian Ministry of Human Resource. (2013). Malaysian Standard Classification of Occupation. Synthesis (3rd ed.). Ministry of Human Resources Malaysia. Retrieved from http://www.mohr.gov.my/index.php/en/2015-05-06-04-09-30/publication/2016-03-08-02-0700/167-masco-2013

Mansor, N., \& Kennedy, J. (2000). Malaysian Culture and the Leadership of Organisations : A GLOBE Study.

Martin, G. S., Keating, M. A., Resick, C. J., Szabo, E., Kwan, H. K., \& Peng, C. (2013). The meaning of leader integrity: A comparative study across Anglo, Asian, and Germanic cultures. Leadership Quarterly, 24(3), 445-461. https://doi.org/10.1016/j.leaqua.2013.02.004

Mintzberg, H. (1973). The Nature of Managerial Work. Harper and Row.

Mizan, K., Nawawi, Z. A., Azlin, A. S., \& Salin, P. (2016). Internal Controls and Fraud: Empirical evidence from oil \& gas company. Journal of Financial Crime, 23(4). https://doi.org/10.1108/13590791011082797

Mucciarone, M. A. (2008). Accountability and Performance Measurement in Australian and Malaysian Government Departments.

Mucciarone, M. A., \& Neilson, J. (2011). Performance Reporting in The Malaysian Government. Asian Academy of Management Journal of Accounting and Finance, 7(2), 35-77. https://doi.org/10.1057/jdg.2010.4

Ofori, W. (2011). Effectiveness of Internal Controls: A perception or Reality? The Evidence of Ghana Post Company Limited in Ashanti Region, 69.

Petrovits, C., Shakespeare, C., \& Shih, A. (2011). The causes and consequences of internal control problems in nonprofit organizations. Accounting Review, 86(1), 325-357. https://doi.org/10.2308/accr.00000012

Poole, S. (2013). The Right to be Lazy. New Statesmen, 142(5187), 22-25. https://doi.org/10.1016/S0262-4079(14)61810-8

Public Service Department of Malaysia. (2002). Laporan Penggredan Jawatan. Malaysia. Retrieved from http://docs.jpa.gov.my/docs/pekeliling/pp02/bil04/Lampiran-B3.pdf\#p1

Publics Service Department of Malaysia. (2011). Public Service Department Annual Report. Malaysia.

Reckless, W. C. (1961). A New Theory of Deliquency and Crime. Federal Probation, 25(42).

Rosli, M. H., Aziz, M. A., Mohd, F., \& Said, J. (2015). Integrity Systems in Malaysian Public Sector: An Empirical Finding. Procedia Economics and Finance, 28(April), 260-265. https://doi.org/10.1016/S2212-5671(15)01109-0

Schraw, G., Wadkins, T., \& Olafson, L. (2007). Doing the things we do: A grounded theory of academic procrastination. Journal of Educational Psychology, 99(1), 12-25. https://doi.org/10.1037/0022-0663.99.1.12

Servais, J.-M., \& Blanpain, R. (2011). International Labour Law. Kluwer Law International Alphen aan den Rijn.

Shields, M. D., Deng, F. J., \& Kato, Y. (2000). The design and effects of control systems: tests of direct- and indirect-effects models. Accounting, Organizations and Society, 25(2), 185-202. https://doi.org/10.1016/S0361-3682(99)00041-0

Simer, J. B. and B. (2013). COSO Enhances Its Internal Control - Integrated Framework. Retrieved December 6, 2016, from http://deloitte.wsj.com/riskandcompliance/2013/06/12/cosoenhances-its-internal-control-integrated-framework/

Snider, L. (2002). Theft of Time : Disciplining Through Science and Law. Sociology The Journal Of The British Sociological Association, 40(1), 89-112. 
Soans, A., \& Abe, M. (2016). Bribery, Corruption and Bureaucratic Hassle: Evidence from Myanmar. Journal of Asian Economics, 44, 41-56. https://doi.org/10.1016/j.asieco.2016.04.003

Spira, L. F., \& Page, M. (2003). Risk management: The reinvention of internal control and the changing role of internal audit [Electronic Version]. Accounting, Auditing \& Accountability Journal, 16(4), 640-661. https://doi.org/10.1108/09513570310492335

Staicu, A. M., Tatomir, R. I., \& Lincă, A. C. (2013). Determinants and Consequences of "Tone at the Top ." International Journal of Advances in Management and Economics, 2, 76-88.

Wessel, J., Bradley, G. L., \& Hood, M. (2019). Comparing Effects of Active and Passive Procrastination: A field study of behavioral delay. Personality and Individual Differences, 139(July 2018), 152-157. https://doi.org/10.1016/j.paid.2018.11.020

White, M. D. (2012). Kantian Moral Psychology and Criminal Behavior. Journal of Criminal Psychology, 2(1), 67-76. https://doi.org/10.1108/20093821211210503

Yu, S., \& Neter, J. (1973). A Stochastic Model of the Internal Control System. Journal of Accounting Research, 273-295. https://doi.org/10.1360/zd-2013-43-6-1064 